\title{
PROFIL PEMAHAMAN KONSEP SISWA DITINJAU DARI TINGKAT KEMAMPUAN MATEMATIKA PADA MATERI FUNGSI KOMPOSISI
}

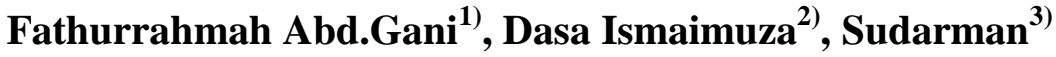 \\ Fathurrahmahfarah@gmail.com ${ }^{1)}$,dasaismaimuza@yahoo.co.uk ${ }^{2}{ }^{\prime}$, sudarmanbennu@gmail.com $^{3)}$
}

\begin{abstract}
Abstrak: Tujuan penelitian ini adalah mendeskripsikan profil pemahaman konsep siswa kelas X MIA berdasarkan tingkat kemampuan matematika. Penelitian dilaksanakan di MA Alkhairaat Palu menggunakan pendekatan deskriptif kualitatif. Hasil penelitian menunjukkan pemahaman konsep ST dalam mengklasifikasi fungsi komposisi yaitu ada fungsi dan operasi komposisi. Mengidentifikasi sifat, operasi atau konsep siswa menggunakan sifat assosiatif, distributif, operasi komposisi dan hitung aljabar. Menerapkan konsep siswa menjelaskan sifat-sifat dan operasi-operasi. Memberi contoh dan bukan fungsi komposisi siswa menjelaskan contoh yaitu ada operasi komposisi dan bukan yaitu tidak terdapat operasi komposisi. Menyajikan masalah siswa menyajikan dalam bentuk model matematika. Pemahaman konsep SS dalam mengklasifikasi fungsi komposisi yaitu gabungan fungsi dihubungkan dengan operasi komposisi. Mengidentifikasi sifat, operasi atau konsep yaitu sifat distributif, operasi komposisi dan hitung aljabar.Menerapkan konsep siswa menjelaskan sifat-sifat dan operasi-operasi. Memberi contoh dan bukan contoh fungsi komposisi yaitu contoh terdapat operasi komposisi dan bukan yaitu tidak ada operasi komposisi. Menyajikan masalah dalam bentuk model matematika. Pemahaman konsep SR dalam mengklasifikasi fungsi komposisi

yaitu ada operasi komposisi. Memberi contoh dan bukan contoh fungsi komposisi yaitu contoh fungsi komposisi terdapat operasi komposisi dan bukan contoh yaitu tidak terdapat operasi komposisi
\end{abstract}

Kata Kunci: Profil; Pemahaman konsep; Fungsi komposisi

\begin{abstract}
The aim of this research was to describe the profile of understanding the concept of class X MIA students based on the level of mathematical ability. The research was conducted at MA Alkhairaat Palu using a qualitative descriptive approach. The results of the study show that the understanding of the concept of ST in classifying the function of composition is that there is a function and operation of composition. Identify the characteristics of operations or concepts students use associative, distributive, composition operations and algebraic. Applying the concept students explain the properties and operations. Giving examples and not the composition function of the students explains the example, that there is an operation of composition and not there is no operation of the composition. Presenting the problem students presents in the form of mathematical models. Understanding the SS concept in classifying composition functions, namely a combination of functions associated with composition operations. Identify the characteristics of operations or concepts, namely the nature of distributive, operating composition and calculating algebra. Applying the concept students explain the properties and operations. Give an example and not an example of a composition function is an example is that there is a composition operation and not that there is no composition operation. Presenting problems in the form of mathematical models. Understanding the concept of SR in classifying the function of composition, namely there is a composition operation. Give an example and not an example of a composition function, is an example there is a composition operation and not an example, that is, there is no composition operation.
\end{abstract}

Keywords: Profile; Understanding of concepts; Composition function

Tujuan matapelajaran matematika dalam kurikulum 2013 (Kemendikbud, 2017) adalah agar siswa dapat (1) memahami konsep matematika mencakup kompetensi dalam menjelaskan keterkaitan antar konsep dan menggunakan konsep ataupun algoritma secara luwes, akurat, efsien, dan tepat dalam pemecahan masalah., (2) Menggunakan pola sebagai 
dugaan dalam penyelesaian masalah dan mampu membuat generalisasi berdasarkan fenomena atau data yang ada, (3) Menggunakan penalaran pada sifat, melakukan manipulasi matematika, baik dalam penyederhanaan, maupun menganalisis komponen yang ada dalam pemecahan masalah dalam konteks matematika ataupun di luar matematika (kehidupan nyata,ilmu, dan teknologi), (4) Mengomunikasikan gagasan, penalaran serta mampu menyusun bukti matematika dengan menggunakan kalimat lengkap, simbol, tabel, diagram,atau media lain untuk memperjelas keadaan atau masalah, (5) Memiliki sikap menghargai kegunaan matematika dalam kehidupan, yaitu memiliki rasa ingin tahu, perhatian, dan minat dalam mempelajari matematika,serta sikap ulet dan percaya diri dalam pemecahan masalah, (6) Memiliki sikap dan perilaku yang sesuai dengan nilai-nilai dalam matematika dan pembelajarannya seperti taat azas, konsisten, menjunjung tinggi kesepakatan, toleran.

Satu diantara tujuan tersebut yaitu agar siswa memahami konsep matematika.Untuk memahami konsep matematika, maka diperlukan kemampuan siswa yang baik dalam menguasai konsep matematika dan peran guru sangat penting untuk memfasilitasi siswa memiliki kemampuan yang baik dalam memahami konsep matematika. Satu diantara materi matematika yang dipelajari siswa di tingkat SMA/MA adalah materi fungsi komposisi. Namun, siswa masih mengalami kesulitan dalam memahami konsep dan sifat-sifat fungsi komposisi, serta siswa juga melakukan kesalahan prosedural. Penelitian tentang pemahaman siswa terkait konsep fungsi komposisi juga pernah dilakukan oleh Basri (2017) penelitiannya menunjukkan bahwa siswa masih keliru dalam memahami konsep fungsi komposisi, siswa menganggap komposisi fungsi sama dengan substitusi bahkan siswa yang lain menyatakan komposisi sama dengan perkalian fungsi. Satu diantara aspek penting yang harus diketahui oleh guru untuk dapat mengajarkan fungsi komposisi dengan baik adalah perlu untuk mengetahui karakteristik siswanya dalam memahami konsep. Untuk dapat mengetahui karakteristik dari masing-masing siswa dalam memahami konsep, guru perlu untuk mengetahui gambaran pemahaman konsep siswa. Gambaran pemahaman konsep penting untuk diketahui oleh setiap guru, karena dengan gambaran pemahaman konsep tersebut guru dapat mengetahui pemahaman konsep siswa. Aspek-aspek yang belum dan telah diketahui oleh siswa serta cara-cara yang dilakukan oleh siswa dalam menyelesaikan soal matematika khususnya materi fungsi komposisi sehingga nantinya guru dapat merancang suatu pembelajaran dan menentukan metode yang sesuai dengan masalah yang dihadapi oleh siswa.

Rumusan masalah dalam penelitian ini adalah bagaimanakah profil pemahaman konsep siswa terhadap materi fungsi komposisi di kelas X MIA MA Alkhairaat Pusat Palu berdasarkan tingkat kemampuan matematika ? Tujuan penelitian ini adalah mendeskripsikan profil pemahaman konsep siswa terhadap materi fungsi komposisi di kelas X MIA MA Alkhairaat Pusat Palu berdasarkan tingkat kemampuan matematika.

\section{METODE PENELITIAN}

Jenis penelitian ini adalah penelitian kualitatif dengan pendekatan deskriptif kualitatif. Subjek dalam penelitian ini siswa kelas X MIA 1 MA Alkhairaat Pusat Palu. Pemilihan subjek yaitu berdasarkan analisis hasil ulangan harian untuk mengelompokkan siswa berkemampuan matematika tinggi, siswa berkemampuan matematika sedang dan siswa berkemampuan matematika rendah berdasarkan skala penilaian yang ditetapkan oleh Arikunto (2012) yaitu: 1) siswa berkemampuan tinggi jika $80 \leq$ nilai $\leq 100$, 2) siswa berkemampuan sedang jika $56 \leq$ nilai $\leq 79,3$ ) siswa berkemampuan rendah jika $30 \leq$ nilai $\leq$ 
55. Kemudian dipilih masing-masing satu siswa dari kemampuan tinggi, satu siswa dari kemmapuan sedang dan satu siswa dari kemampuan rendah dengan berdasarkan pertimbangan guru, kemampuan komunikasi yang baik dan kesediaan untuk berpartisipasi dalam penelitian.

Jenis data yang digunakan dalam penelitian ini yaitu data profil pemahaman konsep siswa berdasarkan indikator pemahaman konsep. Teknik pengumpulan data yang digunakan yaitu tes tertulis dan wawancara. Instrumen penelitian terdiri atas intrumen utama yaitu peneliti dan instrumen pendukung yaitu tes tertulis. Tes berisi masalah fungsi komposisi yang terdiri atas dua masalah yang setara yaitu, Masalah 1 : Fungsi-fungsi $f, g$ dan $h$ adalah pemetaan dari $\mathbb{R}$ ke $\mathbb{R}$ masing-masing ditentukan dengan rumus $f(x)=2 \mathrm{x}-1, g(x)=4 \mathrm{x}+5$ dan $h(x)=2 \mathrm{x}-3$. Tunjukkan bahwa $(f \circ(g \circ h))(x)=((f \circ g) \circ h)(x)$. Analisis data dilakukan berdasarkan analisis data kualitatif menurut Miles, Huberman, dan Saldana (2014) yaitu : kondensasi data, penyajian data dan kesimpulan. Pengujian kredibilitas data yang dilakukan dalam penelitian ini adalah triangulasi waktu.

\section{HASIL PENELITIAN}

Pengelompokkan siswa berdasarkan kemampuan matematika, yaitu 5 siswa berkemampuan tinggi, 7 siswa berkemampuan sedang, dan 4 siswa berkemampuan rendah. Kemudian dari setiap tingkat kemampuan matematika dipilih masing-masing satu siswa yang dijadikan subjek penelitian, dengan skor tertinggi pada kelompok kemampuan tinggi, pada kategori kemampuan sedang diambil siswa yang berada pada skor median, dan skor terendah diambil pada kategori kelompok kemampuan rendah. Ketiga siswa tersebut diberi inisial ST untuk siswa berkemampuan tinggi, SS untuk siswa berkemampuan sedang dan SR untuk siswa berkemampuan rendah. Menguji kredibilitas data dilakukan dengan triangulasi waktu yaitu memberikan dua masalah yang setara di waktu yang berbeda yaitu M1 untuk masalah 1 dan M2 untuk masalah 2. Data yang dianalisis dalam penelitian adalah profil pemahaman konsep siswa berdasarkan indikator pemahaman konsep dalam menyelesaikan M1.

\section{Profil Pemahaman Konsep Siswa Berkemampuan Matematika Tinggi (ST)}

Hasil tes tertulis ST dalam mengklasifikasi fungsi komposisi berdasarkanciri-ciri pada fungsi komposisi.

\section{$(F \cdot(G \circ h))(x)=((F \circ G) \circ)(x)$}

M1ST01

Gambar 1. Jawaban ST dalam mengklasifikasi fungsi komposisi pada M1

Gambar 1 menunjukkan ST menuliskan bentuk fungsi komposisi yaitu $(f \circ(g \circ h))(x))$ $=(f \circ g) \circ h)(x))($ M1ST01). Guna memperoleh informasi lebih lanjut, peneliti melakukan wawancara dengan ST. Berikut ini adalah petikan hasil wawancara peneliti dengan ST dalam mengklasifikasikan fungsi komposisi pada M1:

PN 05 M1 : dari masalah ini apa yang kamu dapat?

ST 06 M1 : ada 3 fungsi, $f(x), g(x)$, dan $h(x)$, baru nanti di komposisikan

PN 07 M1 : apakah kamu tau ini bentuk fungsi apa ? (sambil menunjuk bentuk $\left(f^{\circ}(g \circ h)\right)(x)$ )

ST 08 M1 : fungsi komposisi

PN 09 M1 : kenapa dikatakan fungsi komposisi ?

ST 10 M1 : eh anu, karena (sambil berpikir) ada dotnya

Hasil wawancara menunjukkan ST mengidentifikasi ciri-ciri yang terdapat pada fungsi komposisi yaitu ada fungsi (ST 06 M1) dan operasi "dot" atau "bundaran" (ST 10 M1) dalam hal ini operasi komposisi. Analisis data pemahaman konsep ST dalam mengklasifikasi fungsi komposisi yaitu menentukan bagian-bagian pada fungsi komposisi. 
Berdasarkan ciri-ciri yang terdapat pada fungsi komposisi yaitu ada fungsi dan operasi "bundaran" atau operasi komposisi. Sehingga dapat dikatakan bahwa ST mengklasifikasikan fungsi komposisi secara lisan dan tertulis dalam memahami masalah.

Hasil tes tertulis ST dalam mengidentifikasi sifat-sifat operasi atau konsep.

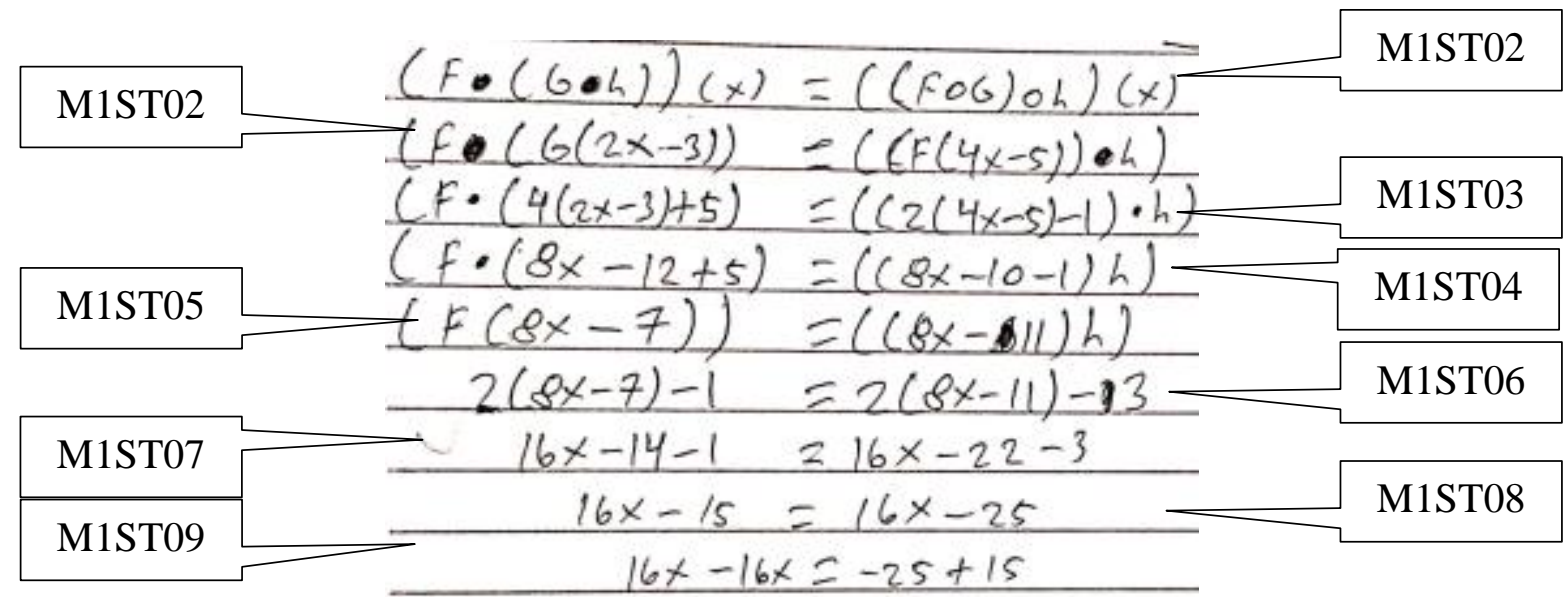

Gambar 2. Jawaban ST dalam mengidentifikasi sifat-sifat operasi atau konsep M1

Gambar 2 menunjukkan ST terlebih dahulu mengerjakan $g \circ h$ di ruas kiri dan $f \circ g$ di ruas kanan (M1ST02), konsep yang digunakan ST yaitu sifat assosiatif. Kemudian langkah selanjutnya ST melakukan operasi komposisi (M1ST03). Langkah berikutnya ST menggunakan konsep sifat distributif (M1ST04), selanjutnya ST menyelesaikan dengan menggunakan operasi hitung aljabar yaitu penjumlahan dan pengurangan (M1ST05). Langkah berikutnya ST kembali menggunakan operasi komposisi untuk menyelesaikan bentuk fungsi komposisi yang kedua (M1ST06) dan kembali menggunakan sifat distributif (M1ST07). Langkah terakhir ST menggunakan operasi hitung aljabar (M1ST08). Guna memperoleh informasi lebih lanjut, peneliti melakukan wawancara dengan ST. Berikut ini adalah petikan hasil wawancara peneliti dengan ST dalam mengidentifikasi sifat-sifat operasi atau konsep pada M1 :

PN 17 M1 : kemudian, bagaimana cara mu menyelesaikan masalah ini ?

ST 18 M1 : pertama $g \circ h$ dulu (sambil menunjuk $\left(f^{\circ}\left(g^{\circ} \boldsymbol{h}\right)\right)(x)$ ) baru itu, hasilnya ini dikomposisikan lagi dengan $f$.

PN 19 M1 : ini kenapa kamu tulis $\left(f^{\circ}(g(2 \mathrm{x}-3))\right.$

ST 20 M1 : karena kan ini $g \circ h$, fungsi $h$ kan 2 x -3, jadi x yang di fungsi $g$ sini diganti jadi fungsi $h$

PN $21 \mathrm{M} 1$ : baru kalau yang ini $((f(4 \mathrm{x}-5)) \circ h)$ ?

ST 22 M1 : sama juga kak, ini kan $f \circ g$ dulu dikerja jadi, $x$ di fungsi $f$ di ganti jadi fungsi $g$

PN 23 M1 : kenapa $f \circ g$ dulu yang dikerja?

ST 24 M1 : karena ada tanda kurungnya kak, jadi dikerja duluan

PN 25 M1 : kemudian ini kenapa kamu tulis $(f \circ(4(2 x-3)+5)$ ?

ST 26 M1 : itu karena sudah diganti $\mathrm{x}$ nya, jadi kan karena fungsi $g$ adalah $4 \mathrm{x}+5$ jadi $\mathrm{x}$ nya di ganti jadi fungsi $h$ baru di komposisikan

PN 27 M1 : baru $f$ dot ini ?

ST $28 \mathrm{M} 1$ : ini nanti kalau $g \circ h$ sudah selesai di komposisikan baru di anu lagi dengan $f$

PN 29 M1 : di anu maksudnya?

ST 30 M1 : di komposisikan kak

PN 31 M1 : baru kalau ini bagaimana ? (sambil menunjuk $((2(4 \mathrm{x}-5)-1) \circ h)$ 
ST 32 M1 : sama juga kak, kan fungsi $f$ adalah $2 x-1$ jadi $x$ nya di ganti jadi fungsi $g$ yaitu $4 x+5$, disini saya salah tulis kak, seharusnya + bukan kurang. jadi nanti hasil kebawahnya ini salah juga kak

PN 39 M1 : kemudian lanjut, ini kenapa kamu tulis $(f \circ(8 x-12+5)$ ?

ST 40 M1 : hasil yang diatasnya ini kak (sambil menunjuk $\left(f^{\circ}(4(2 \mathrm{x}-3)+5)\right)$

PN $41 \mathrm{M} 1$ : coba jelaskan

ST 42 M1 : ini dikali masuk kak, 4 dikali 2x baru 4 dikali (-3) baru +5

PN 43 M1 : kalau yang ini ? (sambil menunjuk $((8 \mathrm{x}-10-1) h)$ ?

ST 44 M1 : sama juga kak hasil yang dari atasnya, 2 dikali 4x baru 2 dikali (-1) baru -1

PN 45 M1 : baru ini mana dotnya ? (sambil menunjuk $((8 \mathrm{x}-10-1) \boldsymbol{h})$

ST 46 M1 : lupa saya tulis kak

PN 47 M1 : selanjutnya yang ini, kenapa kamu tulis $2(8 x-7)-1$ ?

ST 48 M1 : kan hasilnya $g \circ h$ itu $8 \mathrm{x}-7$, baru fungsi $f$ kan $2 \mathrm{x}-1$, jadi di komposisikan fungsi $8 \mathrm{x}-7$ ke fungsi $f$ ini

PN 49 M1 : kalau yang ini $2(8 x-11)-3$ ?

ST 50 M1 : sama juga kak, hasilnya $f \circ g$ di komposisikan dengan $h$, tapi disini saya salah kak, seharusnya fungsi $h$ ini yang dimasukkan kedalam $8 x-11$. jadi disini saya salah kak

Hasil wawancara menunjukkan ST dalam mengidentifikasi sifat-sifat operasi atau konsep sesuai dengan sifat-sifat operasi atau konsep yang telah dipaparkan yaitu menggunakan sifat assosiatif (ST 18 M1, ST 24 M1), sifat distributif (ST 42 M1), operasi komposisi (ST 20 M1, ST 22 M1) dan operasi hitung aljabar (ST 44 M1). Analisis data pemahaman konsep ST dalam mengidentifikasi sifat-sifat operasi atau konsep yaitu siswa menggunakan konsep-konsep yang diperlukan untuk menyelesaikan masalah tersebut, adapun konsep-konsep yang digunakan siswa yaitu sifat assosiatif, sifat distributif, operasi komposisi dan operasi hitung aljabar. Namun, ada beberapa langkah siswa masih keliru, sehingga menyebabkan hasil akhir siswa salah. Hal ini menunjukkan bahwa siswa kurang teliti dalam mengerjakan soal.

Berikut ini petikan hasil wawancara peneliti dengan ST dalam menerapkan konsep secara logis serta menjelaskan dengan menggunakan bahasa sendiri dalam menyelesaikan M1:

PN 17 M1 : kemudian, bagaimana cara mu menyelesaikan masalah ini ?

ST 18 M1 : pertama $g \circ h$ dulu (sambil menunjuk $(f \circ(\boldsymbol{g} \circ \boldsymbol{h}))(x)$ ) baru itu, hasilnya ini dikomposisikan lagi dengan $\mathrm{f}$.

PN 23 M1 : kenapa $f \circ g$ dulu yang dikerja ?

ST 24 M1 : karena ada tanda kurungnya kak, jadi dikerja duluan

PN 27 M1 : baru $f$ dot ini ?

ST 28 M1 : ini nanti kalau $g \circ h$ sudah selesai di komposisikan baru di anu lagi dengan $f$

PN 29 M1 : di anu maksudnya?

ST 30 M1 : di komposisikan kak

PN 31 M1 : baru kalau ini bagaimana ? (sambil menunjuk $((2(4 \mathrm{x}-5)-1) \circ h)$

ST 32 M1 : sama juga kak, kan fungsi $f$ adalah $2 x-1$ jadi $x$ nya di ganti jadi fungsi $g$ yaitu $4 x+5$, disini saya salah tulis kak, seharusnya + bukan kurang. jadi nanti hasil kebawahnya ini salah juga kak

PN 33 M1 : kenapa bisa salah tulis ?

ST 34 M1 : salah liat saya kak

PN 39 M1 : kemudian lanjut, ini kenapa kamu tulis $(f \circ(8 x-12+5)$ ?

ST 40 M1 : hasil yang diatasnya ini kak (sambil menunjuk $\left(f^{\circ}(4(2 \mathrm{x}-3)+5)\right)$

PN 41 M1 : coba jelaskan 
ST 42 M1 : ini dikali masuk kak, 4 dikali 2x baru 4 dikali (-3) baru +5

PN 53 M1 : jadi hasil akhirnya berapa kamu dapat?

ST 54 M1 : kalau yang sebelah sini (sambil menunjuk ruas kiri) 16x - 15. kalau yang ini (sambil menunjuk ruas kanan) $16 \mathrm{x}-25$.

PN 55 M1 : baru kenapa ini kamu tulis $16 \mathrm{x}-16 \mathrm{x}=(-25)+15$ ?

ST 56 M1 : saya kelompokkan lagi yang ada x nya kak.

PN 57 M1 : baru kenapa tidak dilanjutkan?

ST 58 M1 : seharusnya sampe sini saja kak (sambil menunjuk $16 x-15=16 x-25$ ) yang ini tidak usah (sambil menunjuk 16x $-16 x=(-25)+15)$

PN 59 M1 : kenapa tidak usah?

ST 60 M1 : karena nanti x nya jadi nol

PN 61 M1 : jadi kesimpulan apa yang kamu dapat?

ST 62 M1 : ini seharusnya bentuk yang ini sama dengan bentuk yang ini, tapi karena saya sudah salah dari atasnya sini kak, jadi salah juga jawaban ku.

PN 63 M1 : kamu tau sifat apa yang digunakan dalam menyelesaikan masalah ini ?

ST 64 M1 : tidak tau kak, saya cuman tau ini dikomposisikan

PN 65 M1 : apakah bentuk $(f \circ(g \circ h))(x)$ itu sama dengan $((f \circ g) \circ h)(x)$ ?

ST 66 M1 : iya sama kak, hanya cara kerjanya saja yang beda, ini $g \circ h$ dulu yang dikerja, kalau yang ini $f \circ g$ dulu

Hasil wawancara menunjukkan ST menjelaskan dengan menggunakan bahasa sendiri konsep-konsep yang digunakan untuk menyelesaikan masalah fungsi komposisi serta menerapkan konsep secara logis (ST 18 M1, ST 24 M1, ST 32 M1). Adapun konsep yang digunakan ST yaitu sifat asosiatif, sifat distributif, operasi komposisi dan operasi hitung aljabar. Namun, ST tidak mengetahui nama-nama konsep yang digunakan seperti sifat assosiatif, sifat distributif dan operasi hitung aljabar (ST 6 4M1). ST hanya mengetahui cara penggunaan konsep tersebut. ST menyadari adanya kesalahan perhitungan (ST 32 M1) (ST 62 M1) sehingga menyebabkan hasil akhir yang diperoleh adalah keliru (M1ST09). Hasil yang diperoleh tidak sama dengan dugaan awal ST (ST 66 M1). Analisis data pemahaman konsep ST dalam menerapkan konsep secara logis serta menjelaskan dengan menggunakan bahasa sendiri yaitu menjelaskan alasan mengapa menggunakan sifat assosiatif, distributif, operasi komposisi serta operasi hitung aljabar secara logis dalam menyelesaikan masalah dengan langkah-langkah yang benar.

Berikut ini petikan hasil wawancara peneliti dengan ST dalam memberi contoh fungsi komposisi dan bukan contoh dari fungsi komposisi pada M1:

PN 09 M1: kenapa dikatakan fungsi komposisi ?

ST 10 M1: eh anu, karena (sambil berpikir) ada dotnya

PN 11 M1: kapan dia dikatakan bukan fungsi komposisi ?

ST 12 M1: kalau tidak ada dotnya

Hasil wawancara menunjukkan ST memberi contoh fungsi komposisi yaitu terdapat operasi "dot" atau bundaran (ST 10 M1) dan untuk bukan contoh fungsi komposisi yaitu tidak terdapat operasi "dot" (ST 12 M1). Analisis data pemahaman konsep ST dalam memberi contoh fungsi komposisi dan bukan contoh dari fungsi komposisi yaitu ST dalam memberi contoh dan bukan contoh fokus pada ada atau tidak adanya operasi komposisi.

Hasil tes tertulis ST dalam menyajikan suatu masalah fungsi komposisi dalam berbagai bentuk representasi matematis. 


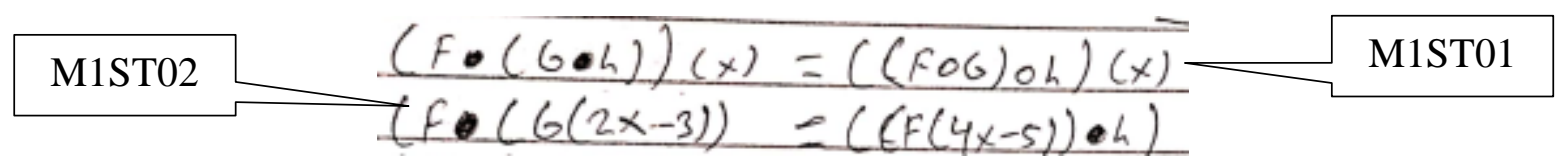

Gambar 3. Jawaban ST dalam menyajikan M1 kedalam berbagai bentuk representasi matematis

Gambar 3 menunjukkan ST menuliskan bentuk fungsi komposisi yaitu $(f \circ(g \circ h))(x))$ $=(f \circ g) \circ h)(x))($ M1ST01). Kemudian langkah selanjutnya ST mengganti fungsi $h$ yaitu $2 \mathrm{x}-$ 3 untuk ruas kiri (M1ST02) dan mengganti fungsi $g$ yaitu 4x - 5 untuk ruas kanan (M1ST02). Guna memperoleh informasi lebih lanjut, peneliti melakukan wawancara dengan ST. Berikut ini petikan hasil wawancara peneliti dengan ST dalam menyajikan suatu masalah fungsi komposisi dalam berbagai bentuk representasi matematis pada M1:

PN 01 M1 : dari masalah ini apa yang kamu pahami ?

ST 02 M1 : yang saya pahami cara kerjanya

PN 03 M1 : bagaimana cara kerjanya?

ST 04 M1 : hasil yang ini (sambil menunjuk bentuk $(f \circ(g \circ h))(x))$ nanti sama dengan yang ini (menunjuk bentuk $((f \circ g) \circ h)(x))$

PN 37 M1 : ini kenapa kamu tulis seperti ini ? ruas kiri dan ruas kanan ?

ST 38 M1 : karena ini yang diminta di soalnya, tunjukkan bahwa $\left(f^{\circ}(g \circ h)\right)(x)$ itu sama dengan $((f \circ g) \circ h)(x)$. jadi saya kerja seperti itu kak

Hasil wawancara menunjukkan ST menyajikan masalah komposisi kedalam bentuk model matematika (ST 04 M1) serta konsisten dalam penggunaanya untuk menyelesaikan masalah komposisi yang diberikan (ST 38 M1). Subjek ST juga mengerjakan sesuai bentuk perintah soal (ST 38 M2) yaitu $\left.\left.\left.\left(f^{\circ}(g \circ h)\right)(x)\right)=(f \circ g) \circ h\right)(x)\right)$ (M1ST01). Analisis data pemahaman konsep ST dalam menyajikan masalah komposisi yaitu ST memilih dengan tepat representasi untuk menyelesaikan dan menyajikan masalah fungsi komposisi yaitu dalam bentuk model matematika.

Profil Pemahaman Konsep Siswa Berkemampuan Matematika Sedang (SS)

Hasil tes tertulis SS dalam mengklasifikasi fungsi komposisi berdasarkan ciri-ciri pada fungsi komposisi.

$($ Fog $h)(x)=x \neq(g \circ h)(x)$

Gambar 4. Jawaban SS dalam mengklasifikasi fungsi komposisi M1

Gambar 4 menunjukkan SS menuliskan bentuk fungsi komposisi yaitu $(f \circ g \circ h)(x)=$ $f(g \circ h)(x)($ M1SS01). Berikut ini adalah petikan hasil wawancara peneliti dengan SS dalam mengklasifikasikan fungsi komposisi pada M1:

PN 03 M1 : kamu tau ini bentuk apa ? (sambil menunjuk $\left(f^{\circ}(g \circ h)(x)\right)$ )

SS 04 M1 : tau, komposisi 3 fungsi

PN 05 M1 : kenapa dikatakan komposisi 3 fungsi ?

SS 06 M1 : karena ada $f g$ dan $h$

PN 07 M1 : kenapa dinamakan komposisi ?

SS 08 M1 : karena digabungkan ketiga fungsi itu jadi satu, yang dihubungkan dengan dot

Hasil wawancara menunjukkan SS mengidentifikasi ciri-ciri yang terdapat pada fungsi komposisi yaitu beberapa fungsi (SS 06 M1) yang dihubungkan dengan operasi "dot" (SS 08 M1). Analisis data pemahaman konsep SS dalam mengklasifikasi fungsi komposisi yaitu SS mengklasifikasikan berdasarkan ciri-ciri yaitu beberapa fungsi yang digabungkan dan dihubungkan dengan operasi komposisi.

Hasil tes tertulis SS dalam mengidentifikasi sifat-sifat operasi atau konsep 
Fathurrahmah Abd. Gani, Dasa Ismaimuza, Sudarman, Profil Pemahaman ... 105

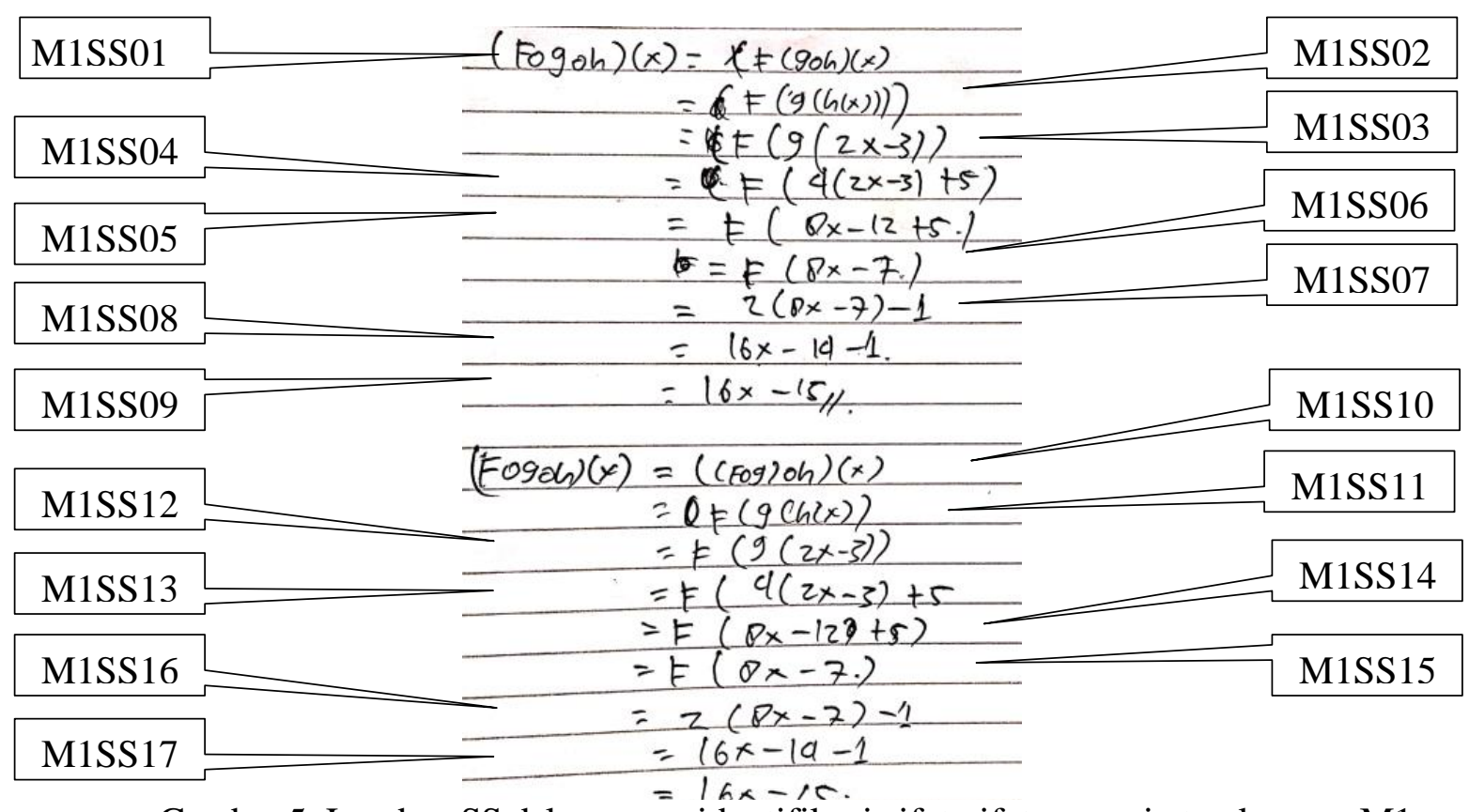

Gambar 5. Jawaban SS dalam mengidentifikasi sifat-sifat operasi atau konsep M1

Gambar 5 menunjukkan SS mengerjakan masalah fungsi komposisi yaitu langkah pertama mengkomposisikan fungsi $g$ dan $h$ (M1SS02) dimana fungsi $h$ yaitu $2 \mathrm{x}-3$ (M1SS03). Langkah selanjutnya SS mengkomposisikan 2x -3 dengan fungsi g yaitu $4 x+5$ (M1SS04) dalam hal ini SS melakukan operasi komposisi dan sifat distributif. Kemudian SS melakukan operasi hitung aljabar (M1SS05) sehingga memperoleh hasil 8x - 7 (M1SS06). Langkah berikutnya SS mengkomposisikan lagi fungsi f dengan fungsi hasil komposisi yang diperoleh dari $g \circ h$ (M1SS07). Kemudian SS menyelesaikan hasil akhir dengan menggunakan sifat distributif (M1SS08) dan operasi hitung aljabar (M1SS09). Langkah berikutnya SS mengerjakan bentuk fungsi komposisi yaitu $((f \circ g) \circ h)(x)$, akan tetapi SS mengerjakan bentuk tersebut sama seperti bentuk sebelumnya (M1SS10) yaitu ( $f^{\circ}$ $(g \circ h))(x)$. Hal ini menunjukkan SS tidak menggunakan sifat assosiatif untuk menyelesaikan masalah fungsi komposisi (M1SS11). Subjek SS hanya menggunakan sifat distributif (M1SS12), operasi komposisi (M1SS15, M1SS11), operasi hitung aljabar (M1SS13, M1SS14, M1SS16) sehingga memperoleh hasil akhir yaitu 16x - 15 (M1SS17). Berikut ini adalah petikan hasil wawancara peneliti dengan SS dalam mengidentifikasi sifat-sifat operasi atau konsep M1:

PN 17 M1 : bagaimana caramu menyelesaikan masalah ini ?

SS 18 M1 : masukan disini saja pertama $h(x)$ bru $g(x)$ baru $f(x)$

PN 19 M1 : baru yang kedua ini ? (menunjuk $((f \circ g) \circ h)(x))$.

SS 20 M1 : sama saja kerjanya tidak ada bedanya.

PN 21 M1 : tanda kurung nya tidak berpengaruh?

SS 22 M1 : tidak kak

PN 23 M1 : kamu tau sifat apa yang digunakan dalam menyelesaikan masalah ini ?

SS 24 M1 : sifat apa kak? komposisi ?

PN 25 M1 : didalam fungsi komposisi ada berapa sifat yang berlaku ?

SS $26 \mathrm{M} 1$ : tidak tau kak

PN 27 M1 : kita lanjut, ini kenapa kamu tulis $(f \circ g \circ h)(x)=f(g \circ h(x))$ ?

SS 28 M1 : itu karena yang dimasukkan dulu yang $h(x)$ kedalam rumus $g(x)$ baru itu dimasukkan lagi kedalam rumus $f(x)$ 
PN 29 M1 : kemudian yang ini kenapa kamu tulis $f(g(2 \mathrm{x}-3))$ ?

SS 30 M1 : itu karena rumus $h(x)$ kan 2x - 3, baru dimasukkan kedalam rumus $g(x)$ yaitu $4 x+5$, makanya dibawahnya sini saya tulis lagi $f(4(2 x-3)+5)$. baru hasilnya itu $f(8 \mathrm{x}-12+5)$ hasilnya $f(8 \mathrm{x}-7)$ baru itu dimasukkan lagi kedalam rumus $f(x)$ yaitu $2 \mathrm{x}-1$. makanya disini saya tulis $2(8 \mathrm{x}-7)-1$. baru kita dapatkan sudah hasilnya 16x - 14 - 1 itu hasil dari dikali ke dalam. baru kita hitung lagi jadi hasil akhirnya $16 x-15$

PN 31 M1 : baru kalau yang di bawah ini ? (sambil menunjuk $((f \circ g) \circ h)(x))$

SS 32 M1 : sama juga cara kerjanya kak, tidak ada bedanya, masukkan pertama rumus $h(x)$ ke dalam rumus $g(x)$ baru itu $f(x)$, nanti hasilnya sama, kan yang diminta disoalnya tunjukkan kalau $(f \circ(g \circ h))(x)$ itu sama dengan $((f \circ g) \circ h)(x)$

Hasil wawancara menunjukkan SS mengerjakan masalah fungsi komposisi untuk bentuk $(f \circ(g \circ h))(x)$ adalah sama cara pengerjaannya dengan bentuk $((f \circ g) \circ h)(x)($ SS20M1). Hal ini menunjukkan SS tidak menggunakan sifat assosiatif untuk menyelesaikan masalah fungsi komposisi yang diberikan (SS22M1). Selanjutnya SS menjelaskan cara mengkomposisikan 3 fungsi (SS28M1). Kemudian untuk menyelesaikan fungsi komposisi SS menggunakan sifat distributif dan operasi hitung aljabar (SS30M1). Analisis data pemahaman konsep SS dalam mengidentifikasi sifat-sifat operasi atau konsep yaitu SS lupa menggunakan konsep sifat assosiatif untuk menyelesaikan masalah fungsi komposisi.

Berikut ini petikan hasil wawancara dengan SS dalam menerapkan konsep secara logis dengan menggunakan bahasa sendiri dalam menyelesaikan M1:

PN 17 M1 : bagaimana caramu menyelesaikan masalah ini ?

SS 18 M1 : masukan disini saja pertama $h(x)$ bru $g(x)$ baru $f(x)$

PN 19 M1 : baru yang kedua ini ? (menunjuk $((f \circ g) \circ h)(x))$.

SS 20 M1 : sama saja kerjanya tidak ada bedanya.

PN $21 \mathrm{M} 1$ : tanda kurung nya tidak berpengaruh ?

SS 22 M1 : tidak kak

PN 23 M1 : kamu tau sifat apa yang digunakan dalam menyelesaikan masalah ini ?

SS 24 M1 : sifat apa kak ? komposisi ?

PN 25 M1 : didalam fungsi komposisi ada berapa sifat yang berlaku ?

SS $26 \mathrm{M} 1$ : tidak tau kak

PN 29 M1 : kemudian yang ini kenapa kamu tulis $f(g(2 \mathrm{x}-3))$ ?

SS 30 M1 : itu karena rumus $h(x)$ kan 2x - 3, baru dimasukkan kedalam rumus $g(x)$ yaitu $4 x+5$, makanya dibawahnya sini saya tulis lagi $f(4(2 x-3)+5)$. baru hasilnya itu $f(8 \mathrm{x}-12+5)$ hasilnya $f(8 \mathrm{x}-7)$ baru itu dimasukkan lagi kedalam rumus $f(x)$ yaitu $2 \mathrm{x}-1$. makanya disini saya tulis $2(8 \mathrm{x}-7)-1$. baru kita dapatkan sudah hasilnya $16 x-14$ - 1 itu hasil dari dikali ke dalam. baru kita hitung lagi jadi hasil akhirnya $16 \mathrm{x}-15$

PN $31 \mathrm{M} 1$ : baru kalau yang di bawah ini ? (sambil menunjuk $((f \circ g) \circ h)(x))$

SS 32 M1 : sama juga cara kerjanya kak, tidak ada bedanya, masukkan pertama rumus $h(x)$ ke dalam rumus $g(x)$ baru itu $f(x)$. nanti hasilnya sama. kan yang diminta disoalnya tunjukkan kalau $(f \circ(g \circ h))(x)$ itu sama dengan $((f \circ g) \circ h)(x)$

PN 33 M1 : jadi apa yang dapat kamu simpulkan dari masalah ini ?

SS 34 M1 : hasil dari $(f \circ(g \circ h))(x)$ itu sama saja dengan $((f \circ g) \circ h)(x)$ yaitu $16 \mathrm{x}-15$

Hasil wawancara menunjukkan SS menjelaskan dengan menggunakan bahasa sendiri konsep-konsep yang digunakan beserta langkah-langkah pengerjaanya. Hal ini menunjukkan SS dapat menerapkan konsep secara logis dan sistematis (SS 30 M1). Beberapa konsep yang digunakan SS yaitu sifat distributif, operasi komposisi dan operasi 
hitung aljabar, kecuali sifat assosiatif (SS 22 M1) SS tidak menggunakannya. Analisis data pemahaman konsep SS dalam menerapkan konsep secara logis serta menjelaskan dengan menggunakan bahasa sendiri yaitu walaupun jawaban akhir SS benar akan tetapi, dalam proses pengerjaan SS masih keliru dalam menggunakan konsep yaitu sifat assosiatif (SS 34 M1). SS tidak sadar melakukan kesalahan yaitu menyamakan proses penyelesaian bentuk $(f \circ(g \circ h))(x)$ dan bentuk $((f \circ g) \circ h))(x)$.

Berikut ini petikan hasil wawancara dengan SS dalam memberi contoh fungsi komposisi dan bukan contoh dari fungsi komposisi pada M1:

PN 03 M1 : kamu tau ini bentuk apa ? (sambil menunjuk $\left(f^{\circ}(g \circ h)(x)\right)$ )

SS 04 M1 : tau, komposisi 3 fungsi

PN 05 M1 : kenapa dikatakan komposisi 3 fungsi ?

SS 06 M1 : karena ada $f g$ dan $h$

PN 07 M1 : kenapa dinamakan komposisi ?

SS 08 M1 : karena digabungkan ketiga fungsi itu jadi satu, yang dihubungkan dengan dot

PN 09 M1 : kapan dia dikatakan bukan fungsi komposisi ?

SS 10 M1 : kalau dotnya ini tidak ad

Hasil wawancara menunjukkan SS memberikan contoh fungsi komposisi yaitu gabungan dari beberapa fungsi yang dihubungkan dengan operasi "dot" atau operasi komposisi (SS 08 M1). Selanjutnya, SS memberikan contoh untuk yang bukan fungsi komposisi yaitu tidak ada operasi "dot" atau operasi komposisi yang menghubungkan fungsi-fungsi tersebut (SS 10 M1). Analisis data pemahaman konsep SS dalam memberi contoh dan bukan contoh dari fungsi komposisi yaitu SS membedakan contoh dan bukan contoh fungsi komposisi yaitu pada operasi komposisinya. Jika operasi komposisi ada maka itu contoh fungsi komposisi, namun jika tidak ada maka bukan contoh dari fungsi komposisi.

Hasil tes tertulis SS dalam menyajikan suatu masalah fungsi komposisi dalam berbagai bentuk representasi matematis.

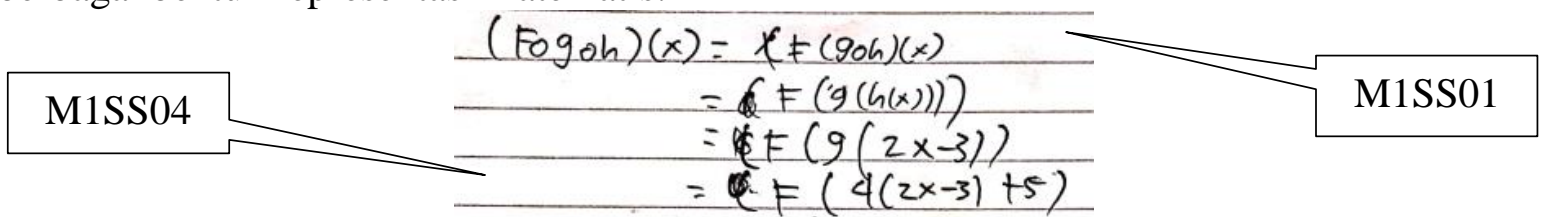

Gambar 6 Jawaban SS dalam menyajikan M1 kedalam berbagai bentuk representasi matematis

Gambar 6 menunjukkan SS menuliskan bentuk fungsi komposisi yaitu $(f \circ g \circ h))(x))=$ $(f \circ g) \circ h)(x)$ ) (M1SS01). Kemudian SS mengganti fungsi $h$ yaitu $2 \mathrm{x}-3$ dan mengganti fungsi $g$ yaitu $4 \mathrm{x}+5$ selanjutnya, mengkomposisikan kedua fungsi tersebut (M1SS04). Berikut ini petikan hasil wawancara dengan SS dalam menyajikan suatu masalah fungsi komposisi dalam berbagai bentuk representasi matematis pada M1:

PN 01 M1 : dari masalah ini apa yang kamu pahami ?

SS 02 M1 : yang saya pahami ada 3 fungsi, yang nanti akan ditunjukkan seperti ini $($ sambil menunjuk $(f \circ(g \circ h)(x))=((f \circ g) \circ h)(x))$

PN 27 M1 : kita lanjut, ini kenapa kamu tulis $(f \circ g \circ h)(x)=f(g \circ h(x))$ ?

SS 28 M1 : itu karena yang dimasukkan dulu yang $h(x)$ kedalam rumus $g(x)$ baru itu dimasukkan lagi kedalam rumus $f(x)$

PN 31 M1 : baru kalau yang di bawah ini ? (sambil menunjuk $((f \circ g) \circ h)(x))$ 
SS 32 M1 : sama juga cara kerjanya kak, tidak ada bedanya, masukkan pertama rumus $h(x)$ ke dalam rumus $g(x)$ baru itu $f(x)$. nanti hasilnya sama. kan yang diminta disoalnya tunjukkan kalau $(f \circ(g \circ h))(x)$ itu sama dengan $((f \circ g) \circ h)(x)$

Hasil wawancara menunjukkan SS membuat model matematika untuk menyelesaikan masalah fungsi komposisi (SS 32 M1) serta mengerjakan secara terpisah bentuk $(f \circ(g \circ h)(x))=((f \circ g) \circ h)(x))$, namun diakhir jawaban tetap mengikuti perintah soal. Analisis data pemahaman konsep SS dalam menyajikan masalah fungsi komposisi dalam bentuk representasi matematis yaitu SS menyajikan masalah dalam bentuk model matematika, cara penyajian data yang dilakukan SS sudah tepat untuk menyelesaikan masalah fungsi komposisi yang diberikan.

Profil Pemahaman Konsep Siswa Berkemampuan Matematika Rendah (SR)

Hasil tes tertulis SR dalam mengklasifikasi fungsi komposisi berdasarkanciri-ciri pada fungsi komposisi.

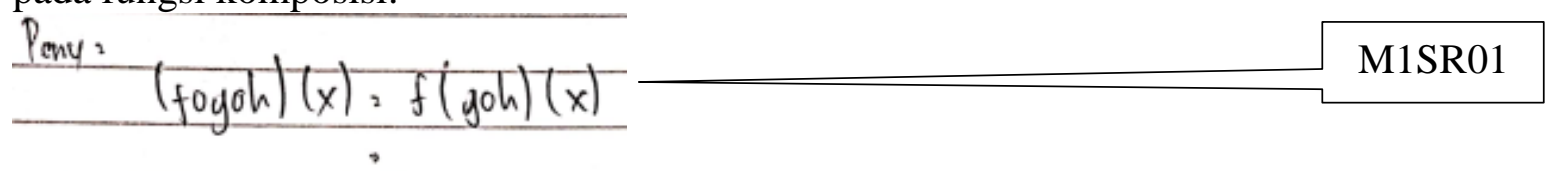

Gambar 7 Jawaban SR dalam mengklasifikasi fungsi komposisi M1

Gambar 7 menunjukkan SR menuliskan bentuk fungsi komposisi yaitu $(f \circ g \circ h))(x))=$ $f(g \circ h))(x))$ (M1SR01). Berikut ini adalah petikan hasil wawancara peneliti dengan SR dalam mengklasifikasikan fungsi komposisi pada M1:

PN 01 M1 : dari masalah ini apa yang kamu pahami ?

SR 02 M1 : saya masih bingung kak

PN 03 M1 : ini kenapa kamu tulis seperti ini $(f \circ(g \circ h)(x))=((f \circ g) \circ h)(x)$ ?

SR 04 M1 : karena itu yang ditanya, jadi saya tulis penyelesaiannya

PN 05 M1 : kenapa tidak dilanjutkan?

SR 06 M1 : saya tidak tau kak, saya tidak paham

PN 07 M1 : kamu tau ini bentuk fungsi apa $\left(f^{\circ}(g \circ h)(x)\right)$ ?

SR 08 M1 : fungsi komposisi kak

PN 09 M1 : kenapa dikatakan fungsi komposisi ?

SR 10 M1 : eehh saya tidak tau kak, tapi karena ada dotnya ini mungkin

PN 11 M1 : yang mana dotnya ?

SR 12 M1 : yang bulat ini kak

Hasil wawancara menunjukkan SR mengidentifikasi ciri-ciri yang terdapat pada fungsi komposisi yaitu ada operasi "dot" atau "bundaran" (SR 10 M1). Analisis data pemahaman konsep SR dalam mengklasifikasi fungsi komposisi yaitu SR mengklasifikasi berdasarkan ciri-ciri yang terdapat pada fungsi komposisi, satu diantaranya yaitu ada operasi komposisi.

Petikan hasil wawancara peneliti dengan SR dalam memberi contoh fungsi komposisi dan bukan contoh dari fungsi komposisi pada M1 sebagai berikut:

PN 07 M1 : kamu tau ini bentuk fungsi apa $(f \circ(g \circ h)(x))$ ?

SR 0 8M1 : fungsi komposisi kak

PN 09 M1 : kenapa dikatakan fungsi komposisi ?

SR 10 M1 : eehh saya tidak tau kak, tapi karena ada dotnya ini mungkin

PN $11 \mathrm{M} 1$ : yang mana dotnya?

SR 12 M1 : yang bulat ini kak

PN 13 M1 : kapan dia dikatakan bukan fungsi komposisi? 
SR 14 M1 : saya tidak tau kak, mungkin kalau tidak ada dotnya

Hasil wawancara menunjukkan SR memberikan contoh fungsi komposisi yaitu dengan mengatakan ada operasi komposisi (SR 10 M1). Kemudian untuk yang bukan contoh dari fungsi komposisi SR mengatakan yaitu tidak ada operasi komposisi (SR 14 M1). Analisis data pemahaman konsep SR dalam memberi contoh dan bukan contoh dari fungsi komposisi yaitu terletak pada operasi komposisi yang disimbolkan dengan "o".

\section{PEMBAHASAN}

Setelah dipilih tiga subjek penelitian berikut ini pembahasan hasil penelitian yaitu profil pemahaman konsep siswa yang berkemampuan tinggi (ST), sedang (SS) dan rendah (SR) pada M1 berdasarkan indikator pemahaman konsep. Hasil tes tertulis dan wawancara yang telah dilakukan dengan ketiga subjek penelitian terlihat bahwa subjek penelitian pada setiap kelompok memiliki pemahaman konsep yang berbeda. Berikut ini pembahasan selengkapnya.

Profil pemahaman konsep ST pada indikator pertama yaitu mengklasifikasi fungsi komposisi, ST menentukan bagian-bagian pada fungsi komposisi berdasarkan ciri-ciri yang terdapat pada fungsi komposisi yaitu ada fungsi dan operasi komposisi. Indikator kedua yaitu mengidentifikasi sifat-sifat operasi atau konsep, ST menjelaskan alasan mengapa menggunakan sifat assosiatif karena pengelompokkan yang terlebih dahulu dikerja, sifat distributif untuk dapat menyelesaikan persamaan, operasi komposisi untuk menyelesaikan fungsi komposisi serta operasi hitung aljabar untuk menyelesaikan hasil. ST terlihat secara sadar menggunakan konsepkonsep tersebut dalam menyelesaikan masalah fungsi komposisi yang diberikan. Hal ini sejalan dengan pendapat Skemp (1976) yaitu siswa yang memiliki pemahaman relasional dapat mengerjakan suatu perhitungan secara sadar dan mengerti proses yang dilakukan. Indikator ketiga yaitu menerapkan konsep secara logis serta menjelaskan dengan menggunakan bahasa sendiri, ST menjelaskan alasan mengapa menggunakan sifat assosiatif, distributif, operasi komposisi serta operasi hitung aljabar secara logis dalam menyelesaikan masalah. Hal ini sejalan dengan pendapat Johnson (2000) yang mengungkapkan bahwa“pemahaman adalah kemampuan untuk menerangkan sesuatu dengan kata-kata sendiri”. Subjek ST juga dapat menjelaskan makna atau maksud soal. Hal ini sesuai pendapat Sutriadi (2017) bahwa siswa berkemampuan tinggi dapat menjelaskan makna atau maksud dari setiap kata atau kalimat pada soal. Indikator keempat yaitu memberi contoh fungsi komposisi dan bukan contoh dari fungsi komposisi yakni ST menjelaskan contoh fungsi komposisi yaitu memiliki operasi komposisi, jika tidak memiliki operasi komposisi ST menyatakan bukan contoh fungsi komposisi.Indikator kelima yaitu menyajikan suatu masalah fungsi komposisi dalam berbagai bentuk representasi matematis menunjukkan bahwa ST mampu menyajikan masalah kedalam bentuk model matematika dengan benar. ST juga mengerjakan masalah sesuai dengan bentuk perintah soal yaitu $(f \circ(g \circ h))(x)=((f \circ g) \circ h))(x)$.

Profil pemahaman konsep SS pada indikator pertama yaitu mengklasifikasikan fungsi komposisi berdasarkan ciri-ciri yang terdapat pada fungsi komposisi, SS mengatakan beberapa gabungan fungsi yang dihubungkan dengan operasi komposisi. Indikator kedua yaitu mengidentifikasi sifat-sifat operasi atau konsep, SS menggunakan sifat distributif, operasi komposisi serta operasi hitung aljabar. Namun, SS melupakan penggunaan sifat assosiatif, sehingga pada proses pengerjaan SS keliru dalam mengerjakan walaupun hasil akhirnya sudah benar.SS ketika diarahkan dapat mengerjakan soal ini dengan benar. Hal ini menunjukkan subjek SS sebenarnya sudah memiliki konsep sifat assosiatif hanya saja belum terbiasa dengan soal seperti ini khususnya bentuk soal fungsi komposisi, sehingga masih salah dalam menjawab 
langkah-langkah pengerjaan soal saat penelitian serta secara tidak sadar melupakan sifat assosiatif. Hal ini sesuai dengan pendapat Skemp (1976) siswa yang memiliki pemahaman instrumental baru berada pada taraf knowing how to dan tidak menyadari proses yang dilakukan. Indikator ketiga yaitu menerapkan konsep secara logis serta menjelaskan dengan menggunakan bahasa sendiri, SS menjelaskan alasan mengapa menggunakan sifat distributif, operasi komposisi serta operasi hitung aljabar. Hal ini sesuai pendapat Carin dan Sund (dalam Susanto, 2013) pemahaman merupakan kemampuan untuk menerangkan dan menginterpretasikan sesuatu, yang berarti bahwa seseorang telah memahami sesuatu atau telah memperoleh pemahaman akan mampu menerangkan atau menjelaskan kembali apa yang telah ia terima. Indikator keempat yaitu memberikan contoh fungsi komposisi dan bukan contoh dari fungsi komposisi, SS memberikan argument dalam membedakan manakah fungsi komposisi dan bukan fungsi komposisi. Indikator kelima yaitu menyajikan suatu masalah fungsi komposisi dalam berbagai bentuk representasi matematis, SS menyajikan masalah sesuai dengan rencana yang telah dipaparkan yaitu dengan membentuk suatu penyajian data dalam bentuk model matematika. SS juga mengerjakan bentuk secara terpisah, namun diakhir jawaban tetap mengikuti perintah soal yaitu bentuk $\left(f^{\circ}(g \circ h)\right)(x)$ dulu dikerja, kemudian bentuk $((f \circ g) \circ h))(x)$.

Profil pemahaman konsep SR dalam mengklasifikasi fungsi komposisi berdasarkan ciri-ciri yang terdapat pada fungsi komposisi yaitu, mengidentifikasi ciri-ciri fungsi komposisi yaitu dengan mengatakan ada operasi komposisi. Indikator keempat yaitu memberi contoh fungsi komposisi dan bukan contoh dari fungsi komposisi, SR memberikan argument dalam membedakan manakah contoh fungsi komposisi dan bukan fungsi komposisi.

\section{KESIMPULAN}

Pemahaman konsep siswa berkemampuan matematika tinggi (ST) yaitu dapat mengklasifikasi, mengidentifikasi, menerapkan, memberi contoh dan bukan contoh, serta menyajikan masalah. Pemahaman konsep siswa berkemampuan matematika sedang (SS) yaitu dapat mengklasifikasi, mengidentifikasi, menerapkan, memberi contoh dan bukan contoh, serta menyajikan masalah. Namun, dalam mengidentifikasi subjek SS tidak dapat mengidentifikasi sifat assosiatif. Pemahaman konsep siswa berkemampuan matematika rendah (SR) dapat mengklasifikasi serta memberi contoh dan bukan contoh.

\section{SARAN}

Guru sebaiknya lebih memperhatikan pemahaman konsep siswa, karena pemahaman konsep siswa dibutuhkan agar siswa tidak mengalami kesulitan dalam mempelajari materi selanjutnya.Untuk penelitian selanjutnya dapat memanfaatkan hasil penelitian ini yaitu dapat dijadikan sebagai referensi untuk penelitian yang lebih lanjut.

\section{DAFTAR PUSTAKA}

Basri, M. (2017). Deskripsi Pemahaman Konsep Fungsi. Jurnal Nalar Pendidikan,Vol. 5 No.2.[online].Tersedia:http://ojs.unm.ac.id/nalar/article/download/4868/2775.

Johnson,D.W dan Johnson, R.T.(1998).Cooperative Learning and Social Interdependence Theory. [online] 
Fathurrahmah Abd. Gani, Dasa Ismaimuza, Sudarman, Profil Pemahaman ... 111

Kementerian Pendidikan dan Kebudayaan Republik Indonesia.(2017).Matematika Untuk $S M A / M A / S M K / M A K$ Kelas X. Jakarta: Balitbang, Kemendikbud.

Miles, M.B. Huberman, A.M. Saldana, J.(2014).Qualitative Data Analysis:a methods sourcebook third edition. United States of America: Sage

Skemp, R.(1976).Relational and Instrumental Understanding. Department of Education,University of Warwick First published in Mathematics Teaching,77, 2026.[online].

Susanto,A. (2013). Teori Belajar dan Pembelajaran di Sekolah Dasar. Jakarta:Kencana Prenadamedia Group.

Sutriadi, I.M.A., Paloloang, B, dan Sudarman. (2017). Profil Kemampuan Berpikir Kritis Siswa Kelas VIII SMP Negeri Model Terpadu Madani Palu dalam Menyelesaikan Soal Cerita Luas Permukaan dan Volume Balok. AKSIOMA Jurnal Pendidikan Matematika.Vol.6No.2.[online].Tersedia:http://jurnal.untad.ac.id/jurnal/index.php/A KSIOMA/article/view/8970/7117. 